\title{
ANALISA TEKANAN PADA BANTALAN LUNCUR MENGGUNAKAN MINYAK PELUMAS ENDURO SAE 20W/50 DAN FEDERAL SAE20W/50 DENGAN VARIASI PUTARAN
}

\author{
David M. Hutabarat ${ }^{1}$, Mulfi Hazwi ${ }^{2}$, Taufiq B. N. ${ }^{3}$, Himsar A. ${ }^{4}$, A. Husein Siregar ${ }^{5}$ \\ 1,2,3,4,5 Departemen Teknik Mesin, Fakultas Teknik, Universitas Sumatera Utara \\ Email: davidmhutabarat@gmail.com
}

\begin{abstract}
ABSTRAK
Pelumasan adalah suatu cara untuk mengurangi dan memperkecil gesekan dan keausan diantara permukaan-permukaan yang bergerak relatif satu sama lain dengan menempatkan bahan pelumas diantara kedua permukaan yang bergerak tersebut.Bahan pelumas yang umum digunakan adalah berupa cairan (liquids) dan semi-liquid, tapi dapat juga berupa padat atau gas, atau kombinasi cair padat dan gas. Bahan pelumas dalam wujud cairan sering disebut dengan minyak pelumas. Minyak pelumas banyak digunakan pada motor bakar, baik untuk jenis pembakaran dengan busi (siklus otto) maupun untuk jenis pembakaran dengan tekanan (siklus disel dan siklus dual).Minyak pelumas juga digunakan pada sektor industri, misalnya untuk bantalan, roda gigi, pompa maupun kompresor, turbin dan lain-lain.Banyak jenis-jenis minyak pelumas yang beredar di pasaran saat ini sehingga konsumen bebas memilih jenis minyak pelumas yang digunakan sebagai bahan pelumasan. Khusus pada penelitian ini digunakan dua jenis minyak pelumas yaitu minyak pelumas Enduro SAE 20W/50 dan minyak pelumas Federal SAE 20W/50 sebagai perbandingannya. Dalam penelitian dilakukan perbandingan antara minyak pelumas oli kemasan dengan minyak pelumas oli drum untuk mengetahui pengaruh penggunaan oli drum pada bantalan luncur. Hasil yang diperoleh dari penelitian ini adalah tekanan pada bantalan luncur menggunakan minyak pelumas Enduro SAE 20W/50 $2665 \mathrm{~Pa}$ dan minyak pelumas Federal SAE 20W/50 sebesar $2978 \mathrm{~Pa}$.
\end{abstract}

Kata kunci : Pulumasan, Bantalan Luncur, lubrication, Journal Bearing.

\section{PENDAHULUAN}

Dalam sistem perawatan elemen mesin telah dikenal luas teknik pelumasan, yang berperan penting dalam mengendalikan gesekan dan keausan. Pada mesin-mesin yang mempunyai bagian-bagian bergerak relatif satu sama lain dan saling bergesekan pasti selalu dibubuhkan minyak pelumas ke bagian yang bergesekan tersebut untuk membuat gesekan dan keausan menjadi sekecil mungkin.

Dengan mengendalikan bagian yang bergerak dan bagian yang bergesekan tersebut diharapkan dapat memperpanjang umur dari elemen mesin dan mencegah kegagalan dari elemen mesin tersebut. Oleh karena itu teknik atau sistem pelumasan harus dipertimbangkan dalam setiap perencanaan mesin khususnya yang memiliki bagian yang bergerak dan bergesekan.

Fenomena pelumasan dapat dilihat pada hamper semua jeni bantalan yang berfungsi menumpu poros. Tipe yang paling umum digunakan adalah bantalan gelinding (roller bearing) danbantalan luncur (journal bearing), sebab konstruksinya sederhana, mudah dalam pekerjaan bongkar-pasang, harga relatif murah dan mudah dalam pelumasannya.

Pada bantalan luncur, tipe pelumasan yang bias dijumpai adalah pelumasan hidrodinamis. Bantalan luncur merupakan tipe bantalan hidrodinamis yang aling banyak digunakan dalam praktek.[1] 


\section{TINJAUAN PUSTAKA}

Teknik Pelumasan adalah suatu cara untuk mengurangi dan memperkecil gesekan dan keausan dengan menempatkan suatu lapisan tipis (film) fluida di antara permukaan-permukaan yang bergerak atau bergesek yang selanjutnya disebut bahan pelumas. Bahan pelumas yang umum adalah wujud cair seperti minyak mineral mempunyai kekentalan bervariasi tergantung pada pemakaiannya, biasanya digunakan untuk bantalan pada motor bakar atau mesin-mesin industri. Bahan pelumas semi padat seperti minyak gemuk biasanya digunakan untuk bantalan putaran rendah dan padat seperti grafit dan molybdenum biasanya digunakan pada temperatur yang sangan tinggi.

Pemakaian bahan pelumas sangat luas pada bidang mekanisme mesin antara lain seperti gerakan berputar poros pada bantalan luncurm, jurnal yang berputar pada bantalan, gabungan dari gerakan gelinding atau luncuran pada gigi-gigi roda gigi yang berpasangan, gerakan luncur pada piston terhadap silindernya. Semua mekanisme ini memerlukan pelumasan untuk mengurangi gesekan, keausan, dan panas.

\section{Pelumasan Hidrrodinamis}

Pada gerakan menggelinding, penggelindingan bergerak di atas lapisan tipis minyak dengan kadar terlalu tinggi untuk membiarkan sambungan atau kontak langsung melalui lapisan tipis minyak pelumas tersebut. Gerakan rotasi misalnya pada poros dengan menggunakan bantalan luncur (jurnal). Dengan gerakan ini bahan pelumas di tarik dari celah yang lebar pada bagian atas ke bagian yang sempit di sebelah bawah, sehingga membentuk oil wedge yang memisahkan kedua permukaan. Berikut adalah gambar pelumasan hidrodinamis.

\section{Kekentalan minyak pelumas (Viscosity) \\ Kekentalan dinamik dan kekentalan kinamatik}

Dalam industry perminyakan khususnya minyak pelumas dikenal istilah

kekentalan, karena kekentalan merupakan sifat yang paling panting bagi minyak pelumas khususnya dan bahan pelumas umumnya, karena sifat ini menunjukan kemampuan untuk melumasi sesuatu dan kemampuan suatu fluida untuk mengalir dinamik menurut hukum Newton tentang aliran viskos [2]

Dari gambar 2.3 secara matematis dapat ditulis:

$$
\tau=\mu \frac{d u}{d y}=\mu \frac{u}{h}
$$

Sehingga kekentalan dinamik dapat ditulis:

\section{Bantalan Luncur dan Pelumasan pada Bantalan Luncur}

Jenis bantalan luncur (journal bearings) sangat luas penggunaannya pada mesin-mesin yang memiliki elemen berputar (rotating machines), seperti turbin uap, generator, blower, kompresor, motor bakar, poros kapal laut, bahkan sebagai bantalan pada elemen yang seharusnya menggunakan bantalan gelinding (rolling elements bearing). Dalam bahasa inggris disebut journal bearings karena poros ditumpu oleh bantalan pada tempat/daerah yang dinamakan tap-poros atau leher poros (neck), dan daerah leher poros tersebut dinamakan journal.[3]

\section{METODOLOGI PENELITIAN}

Pengujian dilakukan di laboratorium Teknik Pelumasan Departemen Teknik Mesin Fakultas Teknik Universitas Sumatera Utara. Alat yang digunakan adalah Alat uji Bantalan Luncur TM25 buatan TecQuipment Ltd, Inggris. Minyak pelumas yang 
digunakan yaitu minyak pelumas Enduro SAE 20W/50 dan minyak pelumas Federal SAE $20 \mathrm{~W} / 50$.

Spesifikasi Alat Uji Bantalan Luncur adalah sebagai berikut:

- Dimensi Alat Uji:

990 mm x 970 mm x $2850 \mathrm{~mm} 68 \mathrm{~kg}$

- Kondisi operasi:

- Pada jangkauan kelembaban relative setidaknya $80 \%$ pada temperature $<31{ }^{\circ} \mathrm{C}$ dan $50 \%$ pada temperature $40^{\circ} \mathrm{C}$

- Pada Temperatur $+5^{\circ} \mathrm{C}$ sampai $+40^{\circ} \mathrm{C}$

\section{DIAGRAM ALIR PENGUJIAN}

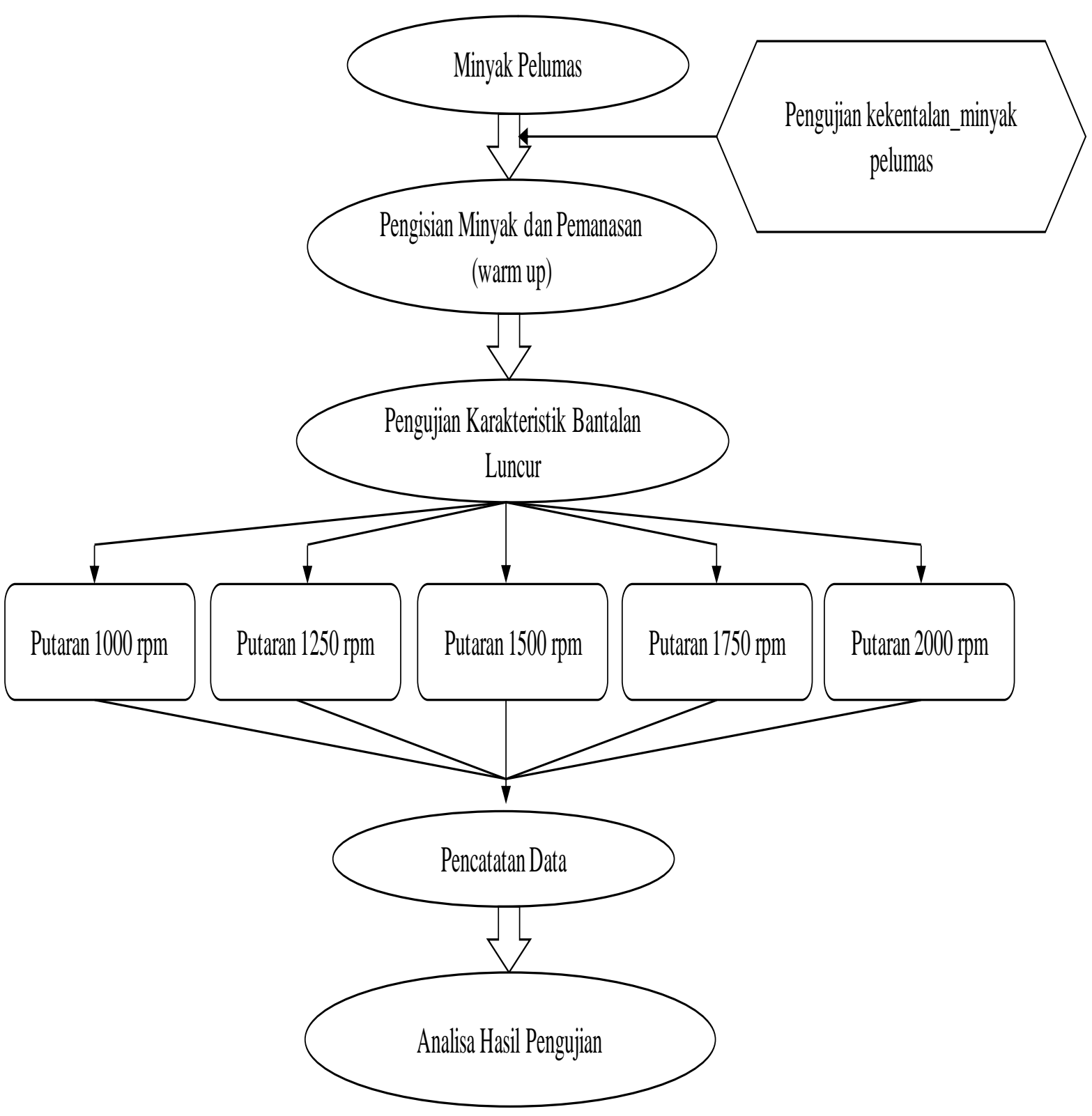


Gambar 3.1 Diagram Alir Pengujian
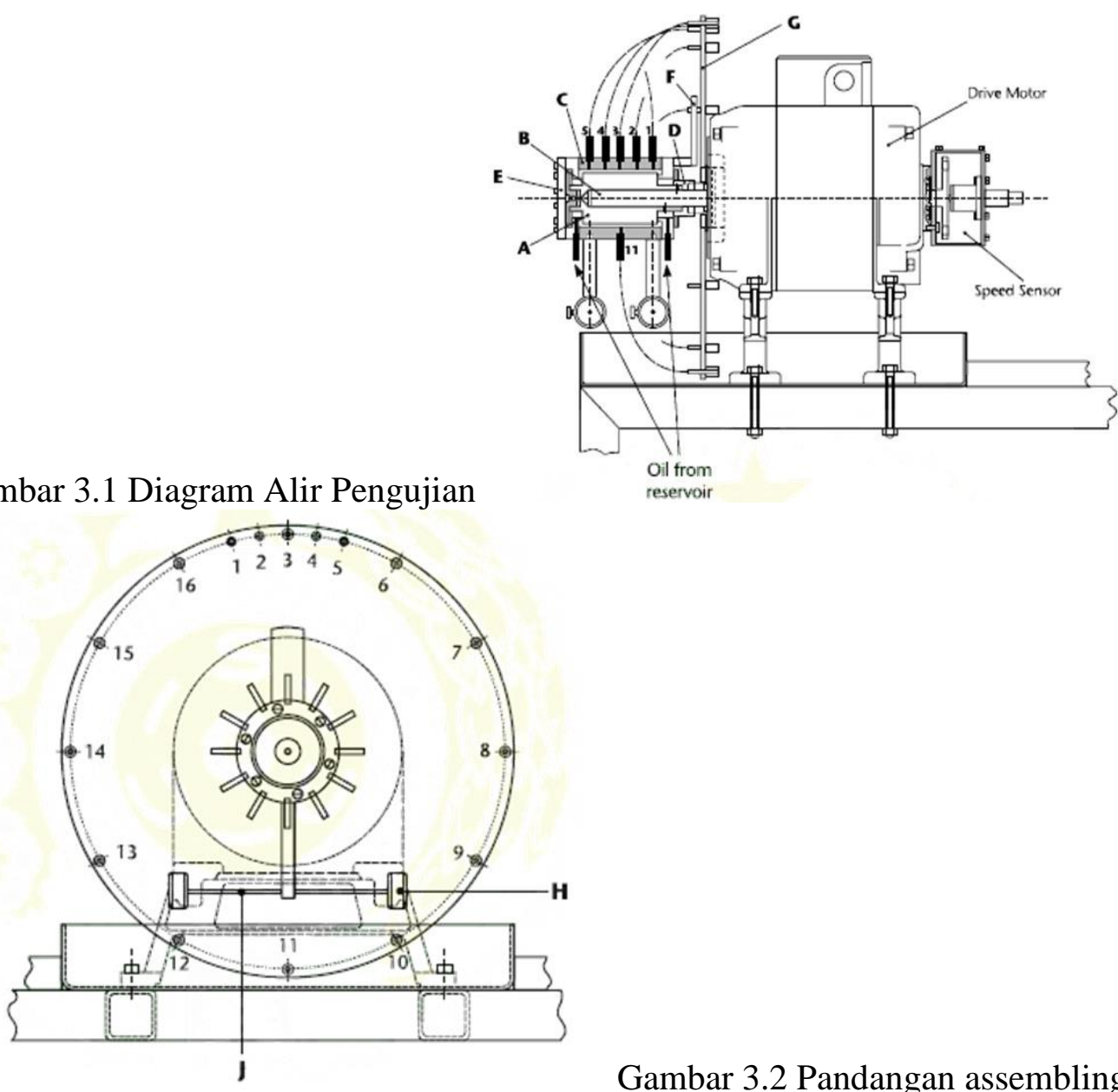

Gambar 3.2 Pandangan assembling peralatan bantalan luncur TM25

Peralatan pengujian bantalan luncur TecQuipment TM25 memiliki reservoir sebagai penampung minyak pelumas. Reservoir dihubungkan dengan dua saluran sebagai pintu masuk minyak pelumas ke dalam bantalan. Reservoir juga dilengkapi dengan keran untuk membuka dan menutup aliran minyak pelumas ke bantalan.

Sebelum melakukan pengujian tekanan pada enam belas titik pengujian harus sama agar terjadi keseimbangan tekanan. Caranya dengan membuka keran masuk minyak pelumas.

Saat pengujian gelembung-gelembung udara harus dikeluarkan agar tidak terjadi kesalahan pembacaan tekanan. Salah satu caranya adalah dengan cara melakukan pemanasan atau warm up. Pemanasan dilakukan dengan menghidupkan motor dan meningkat kecepatan putaran secara bertahap sampai $1500 \mathrm{rpm}$, kemudian dibiarkan sampai satu jam setelah satu jam kecepatan putaran dikutangi hingga stabil pada 1000 rpm selama kira-kira 10 menit.

\section{DATA PENGUJIAN KEKENTALAN MINYAK PELUMAS}

Berikut adalah data-data hasil pengujian kekentalan minyak pelumas yang dilakukan di Laboratorium Fisika Lanjutan Fakultas Teknik Universitas Sumatera Utara. Seperti yang telah dijelaskan pada bab sebelumnya, pengujian kekentalan pada penelitian ini menggunakan bola jatuh menurut Hoeppler.

Data hasil pengukuran kekentalan minyak pelumas Oli Enduro SAE 20W/50 dengan menggunakan Viskometer Bola jatuh Menurut Hoepler [4] 


$$
\begin{aligned}
\Delta t & =\frac{49}{10} \\
& =4,9 \text { detik }
\end{aligned}
$$

Data hasil pengukuran kekentalan minyak pelumas Oli Federal SAE 20W/50 dengan menggunakan Viskometer Bola jatuh Menurut Hoepler

$$
=4,75 \text { detik }
$$

$$
\Delta t=\frac{47,5}{10}
$$

\section{DATA PENGUJIAN DISTRIBUSI TEKANAN}

Pengujian distribusi tekanan pada bantalan luncur dilakukan di laboratorium Mesin Fluida Departemen Teknik Mesin Universitas Sumatera Utara. Alat yang digunakan adalah Alat Uji Bantalan Luncur TM25 buatan TecQuipmant Ltd, Inggris.

Data-data hasil pembacaan tekanaan pada papan manometer peralatan banatalan luncur TecQuipment TM25 menggunakan minyak pelumas Federal Oil SAE 20W/50), serta minyak pelumas oli kemasan Enduro SAE 20W/50.

Perlu diketahui bahwa titik 1.2,3,4 dan 5 berada pada arah aksial (lebar bantalan), sedanakan distribusi tekanan di sekeliling lingkaran (objek utama penelitian ini) ditunjukan oleh titik pengujian 3,6,7,8,9,10,11,12,13,14,15 dan 16. Masing-masing titik pada keliling bantalan berjarak atau membentuk sudut $30^{\circ}$.

\section{MASSA JENIS}

$\rho=\frac{\operatorname{massa}(\mathrm{kg})}{\text { volume }\left(\mathrm{m}^{3}\right)}$

Keterangan:

$\rho=$ massa jenis $\left(\mathrm{kg} / \mathrm{m}^{3}\right)$

$\mathrm{m}=\operatorname{massa}(\mathrm{kg})$

$\mathrm{v}=$ volume $\left(\mathrm{m}^{3}\right)$

Massa jenis minyak pelumas Federal SAE 20W/50

$\rho=\frac{\text { massa }(\mathrm{kg})}{\text { volume }\left(\mathrm{m}^{3}\right)}=\frac{855 \mathrm{gram}}{1 \text { liter }}=\frac{855 \mathrm{gram}}{1 / 1000 \mathrm{~m}^{3}}=\frac{0,855 \mathrm{~kg}}{0,001 \mathrm{~m}^{3}}=855 \mathrm{~kg} / \mathrm{m}^{3}$

Massa jenis minyak pelumas Enduro SAE 20W/50

$\rho=\frac{\text { massa }(\mathrm{kg})}{\text { volume }\left(\mathrm{m}^{3}\right)}=\frac{690 \mathrm{gram}}{0,8 \text { liter }}=\frac{0,69 \mathrm{gram}}{0,8 / 1000 \mathrm{~m}^{3}}=\frac{0,690 \mathrm{~kg}}{0,0008 \mathrm{~m}^{3}}=862,5 \mathrm{~kg} / \mathrm{m}^{3}$

Maka dapat disimpulkan:

$\rho_{\text {Enduro }}>\rho_{\text {Federal }}$

\section{KEKENTALAN (VISCOSITAS)}

Setelah diukur: $\bar{t}$ enduro $=4,9$ detik

$$
\bar{t} \text { federal }=4,75 \text { detik }
$$

Keterangan: Lebih cepat bola jatuh pada minyak pelumas federal

Sedangkan dari rumus:

$$
\mu=\bar{t}(\rho 1-\rho 2) K
$$

Keterangan:

$\bar{t}=$ Waktu rata-rata jatuhnya bola baja (detik)

$\rho 1=$ Massa jenis bola uji $\left(\mathrm{kg} / \mathrm{m}^{3}\right)$

$\rho 2=$ Massa jenis pengukuran minyak pelumas $\left(\mathrm{kg} / \mathrm{m}^{3}\right)$

$\mathrm{K}=$ konstanta bola baja 
$\mu=$ Kekentalan dinamik $(\mathrm{cP})$

Dimana: $\rho$ bola $=\frac{\text { massa }}{\text { volume }}=\frac{50 \mathrm{gram}}{4 / 3 \pi r^{3}}$

Volume bola $=4 / 3 \pi r^{3}$

$\mathrm{r}$ bola $=4 \mathrm{~mm}=0,04 \mathrm{~m}=4 \cdot 10^{-3} \mathrm{~m}$

Berasal dari:

Volume $1 / 2$ bola $=2 \times$ volume kerucut

$$
\begin{aligned}
& =2 \times\left(1 / 3 \pi r^{2} \mathrm{t}\right) \\
& =2 \times\left(1 / 3 \pi r^{2} r\right) \\
& =2 \times 1 / 3 \pi r^{3}=2 / 3 \pi r^{3}
\end{aligned}
$$

Sehingga:

1 bola $=2 \times\left(2 / 3 \pi r^{3}\right)$

Massa 1 bola $=5$ gram $=0,005 \mathrm{~kg}$

Sehingga:

Volume bola $=4 / 3 \pi \mathrm{r}^{3}$

$$
\begin{aligned}
& =4 / 3(3,14)\left(4 \cdot 10^{-3}\right)^{3} \\
& =4 / 3 \cdot 3,14 \cdot 64 \cdot 10^{-9} \\
& =85,3 \cdot 3,14 \cdot 10^{-9} \\
& =267,84 \cdot 10^{-9} \mathrm{~m}^{3}
\end{aligned}
$$

Maka:

$\rho_{\text {bola }}=\frac{\text { massa }}{\text { volume }}=\frac{50 \mathrm{gram}}{4 / 3 \pi r^{3}}=\frac{5 \cdot 10^{-3}}{0,267 \cdot 10^{-9}}=1,86 \cdot 10^{3} \mathrm{~kg} / \mathrm{m}^{3}$

\section{ANALISA HASIL PENGIJUAN KEKENTALAN MINYAK PELUMAS}

Analisa pengujian kekentalan minyak pelumas dilakukan pada data hasil penujian dengan temperature $40^{\circ} \mathrm{C}$.

1. Minyak pelumas oli Enduro SAE $20 \mathrm{~W} / 50$

$$
\begin{aligned}
& \mu=\bar{t} \cdot(\rho 1-\rho 2) \cdot K \\
& =4,9 \cdot(7,7-0,8625) \cdot 12,54 \\
& =4,9 \cdot(6,8375) \cdot 12,54 \\
& =420,137 \mathrm{cP}
\end{aligned}
$$

2. Minyak pelumas oli Federal SAE 20W/50

$$
\begin{aligned}
\mu & =\bar{t} .(\rho 1-\rho 2) . K \\
& =4,75 \cdot(7,7-0,855) \cdot 12,54 \\
& =4,75 \cdot(6,845) \cdot 12,54 \\
& =407,72243 \mathrm{cP}
\end{aligned}
$$

\section{ANALISA PENGUJIAN DISTRIBUSI TEKANAN PADA BANTALAN}

Enam belas titik pengujian pada peralatan bantalan luncur Tec Quipment TM25 menunjukkan distribusi tekanan yang terjadi di sekeliling bantalan luncur. Observasi pada manometer akibat adanya tekanan di sekeliling bantalan luncur, sehingga data yang didapat adalah kenaikan permukaan minyak dalam satuan mm oli, oleh karena itu didapat nilai dari tekanan yang terjadi di sekeliling bantalan:[5]

$$
P=\rho . g .(h 1-h 2)
$$

(Sumber: Analisa karakteristik bantalan luncur terhadap minyak pelumas, tugas sarjana, departemen teknik mesin USU, Medan 2003)

Pada titik 1.

Menggunakan minyak pelumas oli Enduro SAE 20W/50 putaran $1000 \mathrm{rpm}$

$$
\begin{aligned}
\mathrm{P} & =862,5 \cdot 9,81(0,720-0,65) \\
& =862,5 \cdot 9 \cdot 81 .(0,07) \\
& =592,27 \mathrm{~Pa}
\end{aligned}
$$


Menggunakan minyak pelumas oli Federal SAE 20W/50 putaran 1000 rpm

$$
\begin{aligned}
\mathrm{P} & =855.9,81(0,760-0,65) \\
& =855.9 \cdot 81(0,11) \\
& =922,63 \mathrm{~Pa}
\end{aligned}
$$

Hasil Pengijuan Kekentalan Minyak Pelumas

1. Minyak pelumas Enduro SAE 20W/50

$$
\begin{aligned}
\mu & =\bar{t}(\rho 1-\rho 2) K \\
& =4,9(1,86-0,8625) 12,54 \\
& =4,9(0,9975) 12,54 \\
& =61,2923 \mathrm{cP}
\end{aligned}
$$

2. Minyak pelumas Federal SAE $20 \mathrm{~W} / 50$

$$
\begin{aligned}
\mu & =\bar{t}(\rho 1-\rho 2) K \\
& =4,75(7,7-0,855) 12,54 \\
& =4,75(1,005) 12,54 \\
& =59,862 \mathrm{cP}
\end{aligned}
$$

Dimana:

$$
\begin{aligned}
& \rho 1=\text { Massa jenis bola uji }\left(\mathrm{kg} / \mathrm{m}^{3}\right) \\
& \rho 2=\text { Massa jenis pengukuran minyak pelumas }\left(\mathrm{kg} / \mathrm{m}^{3}\right) \\
& \bar{t}=\text { Waktu rata-rata jatuhnya bola baja (detik) } \\
& \mathrm{K}=\text { konstanta bola baja } \\
& \mu=\text { Kekentalan dinamik }(\mathrm{cP})
\end{aligned}
$$

Dengan cara yang sama, maka nilai tekanan untuk setiap putaran poros pada masingmasing titik pengujian dalam satuan Pascal akan didapat.
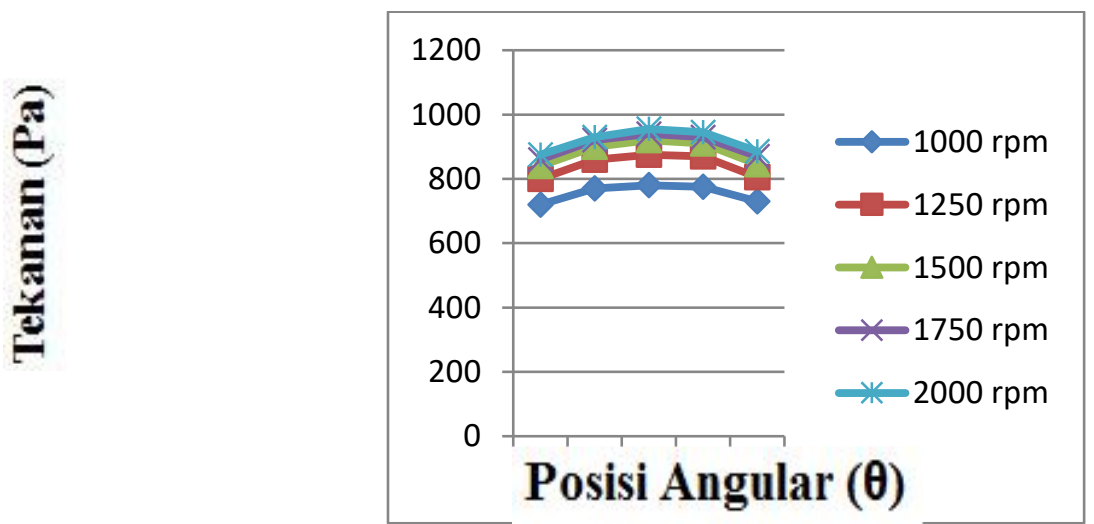

Gambar 4.1 Grafik distribusi tekanan lapisan minyak pelumas arah aksial pada bantalan luncur menggunakan minyak pelumas Enduro SAE 20W/50 


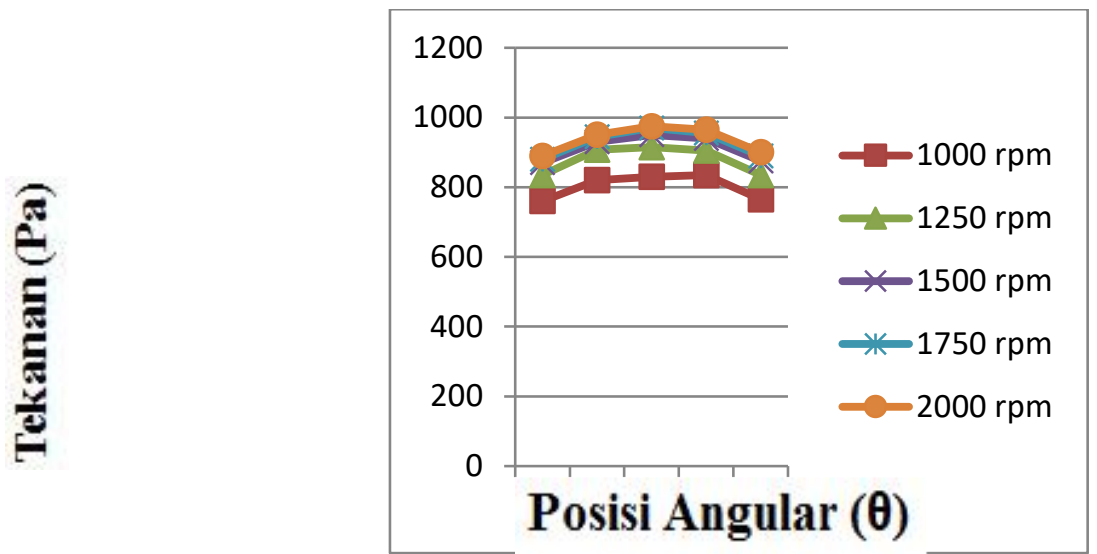

Gambar 4.2 Grafik distribusi tekanan lapisan minyak pelumas arah aksial pada bantalan luncur menggunakan minyak pelumas Federal SAE 20W/50

\section{Lembar diskusi untuk grafik 4.1 - 4.2}

Untuk grafik distribusi tekanan minyak pelumas arah aksial pada bantalan luncur yang menggunakan minyak pelumas oli Enduro SAE 20W/50 dan minyak pelumas oli Federal SAE 20W/50 adalah sebagai berikut:

1. Pada gambar grafik 4.1 yang menggunakan minyak pelumas oli Enduro SAE 20W/50. Tekanan minyak pelumas pada titik 1 belum sampai pada tekanan $800 \mathrm{~Pa}$. Sedangkan pada pada gambar grafik 4.3 yang menggunakan minyak pelumas oli Federal SAE 20W/50, tekanan minyak pelumas pada titik 1 sudah mencapai tekanan $800 \mathrm{~Pa}$.

2. Pada setiap putaran untuk kedua jenis minyak pelumas, tekanan maksimum terjadi pada titik 3 dan kembali turun sampai ke titik 5.

Pada grafik arah aksial pada bantalan luncur tidak terjadi penurunan tekanan minyak pelumas pada bantalan luncur sampai posisi minus karena, posisi titik $1,2,3,4$,dan 5 berada pada arah aksial (lebar) bantalan dan titik tersebut terletak di atas pada bantalan. Sehingga titik 1,2,3,4 dan 5 pada tekanan atmosfer sehingga tidak terjadi vacum (kedap udara)

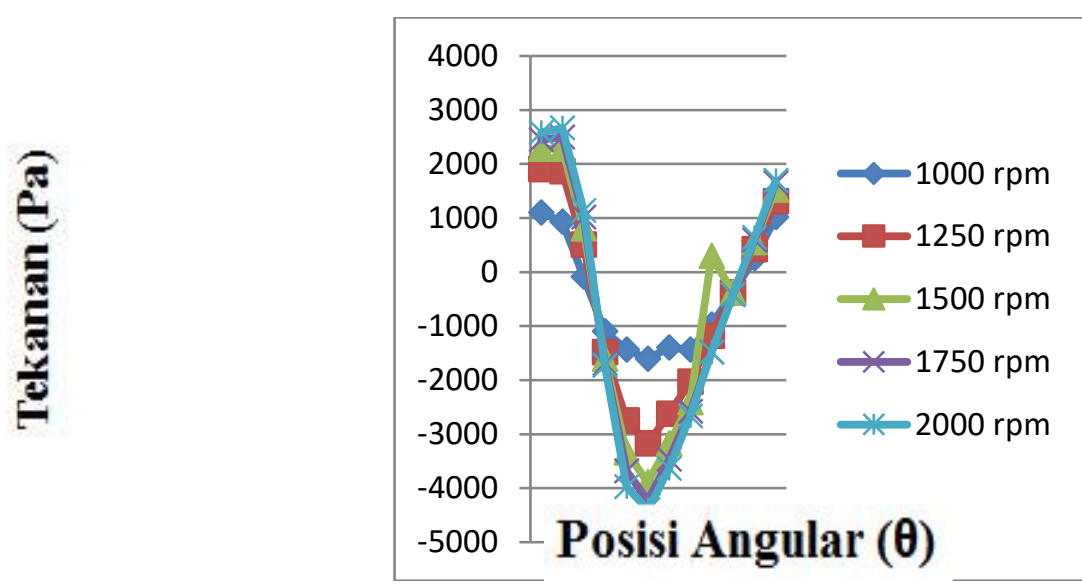

Gambar 4.3 Grafik gabungan distribusi tekanan Sommerfeld hasil eksperimen pada bantalan luncur menggunakan minyak pelumas Enduro SAE 20W/50 


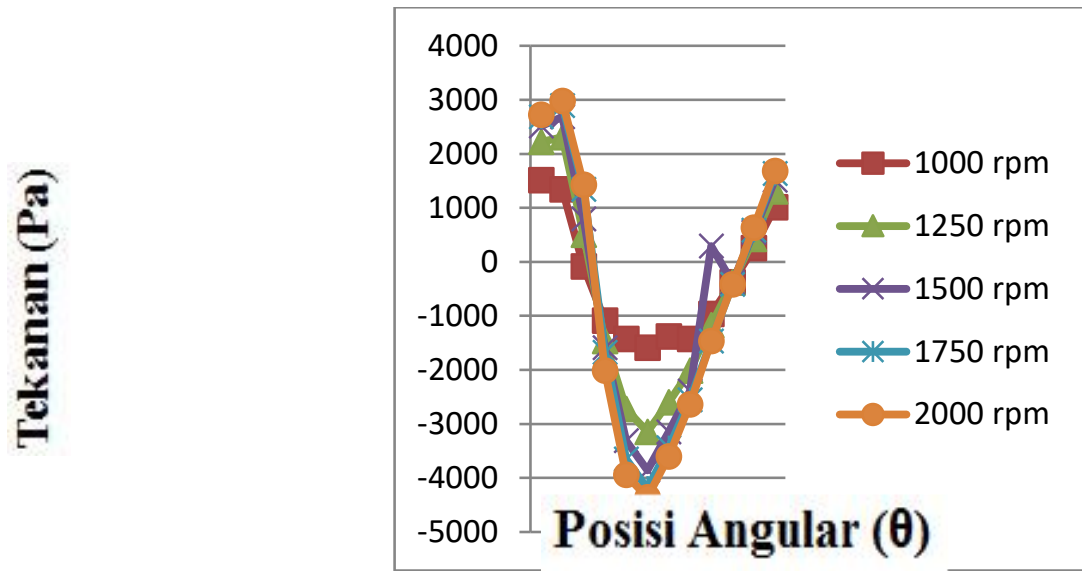

Gambar 4.4 Grafik gabungan distribusi tekanan Sommerfeld hasil eksperimen pada bantalan luncur menggunakan minyak pelumas Federal SAE 20W/50

\section{Lembar diskusi untuk grafik 4.8 - 4.12}

Untuk grafik distribusi tekanan minyak pelumas arah aksial pada bantalan luncur yang menggunakan minyak pelumas oli Enduro SAE 20W/50 dan minyak pelumas oli Federal SAE 20W/50 adalah sebagai berikut:

1. Terjadi gerakan penurunan tekanan minyak pelumas terhadap bantalan luncur, penurunan tekanan dimulai dari titik 8 posisi angular $90^{\circ}$, sampai titik 14 posisi angular $270^{\circ}$. Untuk minyak pelumas oli Enduro SAE 20W/50 terjadi penurunan tekanan khusus pada putaran 1000 terjadi pada titik 7 posisi angular $60^{\circ}$. Penurunan tekanan pada minyak pelumas oli Enduro SAE 20W/50 terjadi sampai titik 14 posisi angular $270^{\circ}$.

2. Sedangkan untuk minyak pelumas oli Federal SAE 20W/50 penurunan tekanan pada grafik terjadi pada titik 8 posisi angular $90^{\circ}$ sampai titik 13 posisi angular $240^{\circ}$.

3. Gerakan penurunan tekanan pada grafik terjadi karena pengaruh tekanan atmosfer, yaitu berada di bawah tekanan atmosfer atau berada pada posisi vacuum (kedap uadar). Terjadi vacuum juga bias dipengaruhi oleh titik observasi pada bantalan luncur yaitu titik $8,9,10,11,12$ dan 13 posisi angular $90^{\circ}, 120^{\circ}, 150^{\circ}, 180^{\circ}, 210^{\circ}$ dan $240^{\circ}$ berada pada bantalan luncur.

4. Grafik kembali naik dimulai dari titik 14 posisi angular $270^{0}$ sampai titik 3 posisi angular $360^{\circ} / 0^{\circ}$, berada di atas pada bantalan luncur dan berada pada tekanan atmosfer. Tetapi pada minyak pelumas oli Enduro SAE 20W/50 gerakan naik dimulai pada titik 15, karena titik 14 masih dalam keadaan vacum.

\section{PENGARUH PUTARAN POROS TERHADAP TEKANAN PADA BANTALAN}

Berdasarkan hasil percobaan terhadap 2 sampel jenis minyak pelumas Enduro dan Federal, pada grafik dapat dilihat perbedaan tekanan yang berbeda pada setiap putaran poros.

Tekanan minyak pelumas Enduro SAE 20W/50 pada bantalan luncur lebih rendah dibandingkan dengan tekanan minyak pelumas Federal SAE 20W/50. Pengaruh perbedaan tekanan diantara kedua jenis sampel minyak pelumas ini karena perbedaan kekentalan, dan penambahan aditif pada oli kemasan yang tidak sesuai dengan rekomendasi pabrik pembuatan aditif. 


\section{KESIMPULAN}

Berdasarkan hasil pengujian tekanan minyak pelumas pada bantalan luncur menggunakan minyak pelumas Enduro SAE 20W/50 dan Federal SAE 20W/50 adalah sebagai berikut:

1. Kekentalan (Viscositas) minyak pelumas Enduro dengan Federal berbeda walaupun memiliki SAE yang sama. Dari hasil penelitian atau pengujian kekentalan (Viscositas) minyak pelumas Enduro lebih tinggi dibandingkan dengan Federal.

2. Perbedaan kekentalan antara minyak pelumas Fedderal dengan Endruo terjadi karena ada kemungkinan penambahan aditif yang terlalu banyak atau berlebihan yang dilakukan oleh produsen karena penambahan aditifharus sesuai dengan rekomendasi pabrikan pembuat aditif tersebut.

Karena aditif dapat memberikan sifat yang baru pada minyak pelumas yang tidak dimikili sebelumnya.

3. Berdasarkan hasil penelitian diperoleh karakteristik distribusi tekanan minyak pelumas Enduro dan Minyak pelumas Federal yaitu:

a) Karakteristik distribusi tekanan minyak pelumas Enduro SAE 20W/50 pada bantalan luncur lebih baik dibandingkan dengan jenis minyak pelumas yang lainnya yang telah diuji.

b) Tekanan yang semakin kecil akibat putaran poros ditingkatkan mengakibatkan titik tengah poros ban bantalan semakin memusat. Sehingga lapisan tipis minyak pelumas pada bantalan akan semakin tebal, yang mengakibatkan berkurangnya tekanan pada dinding bantalan luncur.

4. Peningkatan tekanan terjadi pada minyak pelumas Enduro. Dengan peningkatan tekanan minyak pelumas pada bantalan luncur dapat mengakibatkan usia bantalan luncur menjadi lebih singkat.

5. Berdasarkan hasil penelitian, dari grafik distribusi tekanan Sommerfield terlihat jelas bahwa tekanan minyak pelumas Enduro lebih tinggi dibandingkan minyak pelumas Federal.

\section{DAFTAR PUSTAKA}

[1] Arnell, R. D., "Tribology: Principles and Design Applications", MacMilland Education Ltd, London, 1991.

[2] Hamrock, Bernard. J., "Fundamentals of Fluid Film Lubrication:, 2 ${ }^{\text {nd }}$ edition, Marcel Dekker, Inc., New York, 2004.

[3] Harnoy, Avraham, "Bearing Design in Machinery: Engineering Tribology and Lubrication”, Marcell Dekker, Inc., New York 2003.

[4] Hori, Yukio, "Hidrodynamic Lubrication", Springer-Verlag Tokyo, Tokyo, 2006.

[5] Lansdown, A.R, "Lubrication and Lubricant Selection: A Partical Guide”, 3 rd edition, Profesional Engineering Publishing, London and Bury St Edmuds, 2004

[6] Ludena, K. C., "Friction, Wear, Lubrication : A Textbokk in Trilogy", CRC Press LLC., Michigan, 1996. 